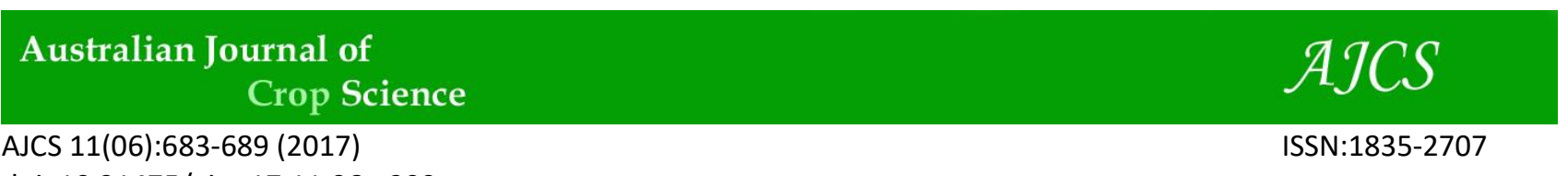

doi: 10.21475/ajcs.17.11.06.p399

\title{
In vitro activity of plant extracts against some important plant pathogenic fungi of tomato
}

\author{
James W. Muthomi ${ }^{1}$, Geraldin M. W. Lengai*1 ${ }^{1}$, Maina J. Wagacha ${ }^{2}$, Rama D. Narla ${ }^{1}$ \\ ${ }^{1}$ Department of Plant Science and Crop protection, University of Nairobi, P. O. BOX 30197, 0100 GPO, Nairobi, \\ Kenya \\ ${ }^{2}$ School of Biological Sciences, University of Nairobi, P. O. BOX 30197, 0100 GPO, Nairobi, Kenya
}

*Corresponding author: lingaig@gmail.com

\begin{abstract}
Indiscriminate use of synthetic pesticides has resulted in loss of access to niche markets due to presence of chemical residues in fresh vegetable produce. There is need for safe alternatives to synthetic pesticides in management of pests and diseases in horticultural production. The objective of this study was to evaluate effectiveness of plant extracts in suppressing growth of plant pathogenic fungi in vitro. Mature plant tissue samples were finely blended, extracted with $95 \%(\mathrm{v} / \mathrm{v})$ ethanol and the extracts were concentrated by evaporation under vacuum at $60^{\circ} \mathrm{C}$ to remove the ethanol. Antifungal activity of the extracts was tested by incorporating the extract into the culture media onto which fungal pathogens were then cultured. Sensitivity of the fungal pathogens was determined by measuring the pathogen colony radial growth of the treatments compared to controls. Extracts from different plants varied in activity, with turmeric extracts being the most active. Turmeric extracts inhibited fungal colony radial growth by 30 to $73 \%$ while mint was the least active. Alternaria solani was the most susceptible pathogen while Pythium ultimum was the most sensitive to extracts from all the plants evaluated. Fusarium oxysporum f. sp. lycopersici was tolerant to most of the plant extracts tested. Sensitivity of all the pathogens tested was found to decrease with the age of the cultures. The study showed that plants extracts contain compounds that inhibit growth of plant pathogenic fungi. Such compounds could be exploited as biopesticides to manage plant diseases thereby reducing the chemical residues in horticultural production.
\end{abstract}

Keywords: Botanical pesticides; integrated pest management; pesticide residues; sustainable agriculture.

\section{Introduction}

Horticulture industry is an important sector in Kenya as it contributes to foreign exchange earnings through exports of fresh fruits and vegetables, creation of employment and income for small scale growers and provision of raw materials for agro-processing industries (Signon, 2015). European Union market accounts for up to $80 \%$ of Kenya's fruit and vegetable sales and $42 \%$ of flower exports (Business Daily, 2014). Growers involved in horticultural production have to maintain the market quality standards of their produce to be aesthetically acceptable and free from pests and diseases by using pest control products that do not leave residues on the produce (Business Daily, 2016). Growers of fresh produce have previously relied on synthetic pesticides, which provide the most convenient way of managing pests and diseases (Birech et al., 2006). The frequent chemical sprays on vegetables have resulted in pest resurgence and resistance (Stangarlin et al., 2011; Wagnitz, 2014; Srijita, 2015), build-up of harmful chemicals in the environment and adverse effects on non-target organisms, in addition to accumulation of pesticides residue on produce (Aktar et al., 2009; Bhattacharjee and Dey, 2014; Business Daily, 2014; Engindeniz et al., 2013; Nderitu et al., 2010). The European Union has set the maximum residue limit (MRL) on all food products at $0.01 \mathrm{mg} / \mathrm{kg}$ (European Commission, 2012). The presence of pesticide residues resulted in rejection of fresh produce in EU market and imposition of up to $10 \%$ sampling per consignment on all beans and peas in pods exported to the EU (European Commission, 2012). Some of the synthetic pesticides have been banned for use in production of fresh vegetables in the last five years due to detection of high levels of harmful chemical residues. The detection of harmful residues resulted in rejection of fresh produce and loss of access to European niche markets (The East African, 2015).

The strict maximum residue level (MRLs) requirements resulted in reduced production and loss of trade for small holder farmers due to non-compliance (KEPHIS, 2012). Therefore, if vegetable farmers are to access the niche EU markets and local supermarkets, there is need to search for alternative pest and disease management approaches that are user friendly and that leave no chemical residues on the produce and in the environment. The most commonly used biological pesticides include living organisms, bioinsecticides, botanicals and compost teas (Mahajan et al., 2015; Prasad and Syed, 2010; Ghorbani et al., 2005). Biological pesticides used to manage pests and diseases in vegetable production include microorganisms such Metarhizium anisopliae, Bacillus thuringiensis, Beauveria bassiana, Pseudomonas syringae, Pantoea agglomerans, Streptomyces lydicus, Bacillus pumilus, Bacillus subtilis, Trichoderma harzianum, Trichoderma virens and Paecilomyces sp. ( Cawoy et al., 2011)and botanicals such as neem (Azadirachtin), pyrethrum, garlic, eucalyptus, turmeric, 
tobacco, ginger; and essential oils such as nettle oil, thyme oil, eucalyptus oil, rue oil, lemon grass oil, tea tree oil; compost extracts and Aloe vera (Gurjar et al., 2012; Shiberu and Getu,2016; Song et al., 2012). Pesticides from natural sources are non-toxic to humans and the environment, are harmless to beneficial insects, are easily degradable, have varied modes of action and they are readily available in the environment compared to the synthetic chemicals (Charlie, 2014; Wagnitz, 2014; Mohammed, 2014, Nashwa, 2011).

The objective of this study was to evaluate the effectiveness of extracts from locally available plants in suppressing growth of plant pathogenic fungi in vitro.

\section{Results}

All the tested plant extracts showed significant $(\mathrm{p} \leq 0.05)$ activity against the tested fungal pathogens (Figure 1; Table 1). The most active extracts were from turmeric (Curcuma longa), lemon (Citrus limon), garlic (Allium sativum), pepper (Capsicum frutescens), ginger (Zingiber officinale), and rosemary (Rosmarinus officinalis) which reduced fungal pathogen colony diameter by between $15-50 \%$. The least active plant extracts were from Mexican marigold (Tagetes minuta), aloe (Aloe vera), neem (Azadirachta indica) and mint (Mentha piperita), which showed a reduction of the fungal pathogen colony diameters of less than $10 \%$, compared to the controls. Among the plant extracts, turmeric was active on all the tested fungal plant pathogens, reducing their colony diameters by up to $72 \%$ on Alternaria solani (Table 1). Garlic was most active on Alternaria solani and Rhizictonia solani while lemon extracts were more effective on Pythium and A. solani. Mexican marigold was only active against Pythium ultimum which was also most sensitive to most of the other plant extracts. There was variation in the activity of the plant extracts during the different stages of growth of the fungal pathogens. The tested fungal pathogens were most sensitive at the early stages of growth of the cultures, with complete inhibition of growth of Alternaria solani by turmeric and garlic extracts (Table 2). Growth of Alternaria solani cultures was inhibited by extracts from all the plant, especially at early stages of growth (Table 2). Extracts from turmeric (Curcuma longa) and lemon (Citrus limon) showed high activity on both young and old cultures of Alternaria, Rhizoctonia, Pythium and Fusarium (Table 2; Table 3; Table 4; Table 5). Extracts from lemon (Citrus limon) were highly effective in reducing the colony radial growth of both young and old cultures of Alternaria solani, Pythium ultimum, Fusarium oxysporum f.sp. lycopersici and Rhizoctonia solani. Cultures of Fusarium oxysporum f.sp. lycopersici were mainly sensitive to extracts from turmeric (Curcuma longa) and lemon (Citrus limon) at all the fungal growth stages (Table 4). Extracts from ginger (Zingiber officinale), rosemary (Rosmarinus officinalis), neem (Azadirachta indica) and aloe (Aloe vera) showed activity only on the young cultures of Rhizoctonia solani (Table 5). Extract from mint (Mentha piperita) and marigold (Tagetes minuta) had no significant effect on Rhizoctonia solani. Old cultures of Rhizoctonia solani were highly tolerant to extracts from ginger (Zingiber officinale), rosemary (Rosmarinus officinalis), neem (Azadirachta indica), aloe (Aloe vera), mint (Mentha piperita) and Mexican marigold (Tagetes minuta) (Table 5).

\section{Discussion}

The evaluated plant extracts inhibited the mycelial growth of the tested tomato fungal pathogens with turmeric (Curcuma longa) being the most active. These findings are in agreement with those reported by Wongkaew and Sinsiri (2014) who found out that ethanolic extracts of turmeric were effective against Alternaria alternata, Pythium sp and Fusarium oxysporum f.sp. lycopersici. Extracts from turmeric have been reported to be effective against Tribolium casteneum, Sitophilus granaries and Rhizopertha dominica (Damalas, 2011). Neem, garlic and ginger extracts have also been reported effective against leaf cutting beetles in mangoes and maize weevils (Sumitra et al., 2012; Nwachukwu and Asawalam, 2014). Chethana et al. (2012) reported that garlic, neem and turmeric extract inhibited growth of Alternaria porri. In addition, plant extracts from garlic (Allium sativum), thorn apple (Datura stramonium), neem (Azadirachta indica) and rosemary (Rosmarinus officinalis) have been reported to reduce early blight in tomato (Nashwa and Abo-Elyousr, 2012; Rodino et al., 2014). Goufo et al. (2010) reported effectiveness of several plant extracts against late blight of tomato

Among the tested pathogens, Rhizoctonia solani and Fusarium oxysporum f.sp. lycopersici were the least susceptible to the extracts. Rodino et al. (2014) reported that marigold (Tagetes minuta) extracts were effective in reducing the mycelial growth of Rhizoctonia solani while Javaid and Rehman (2011) reported that ethyl extracts from neem (Azadirachta indica) were very effective in reducing fungal growth in vitro. Variation in activity of the evaluated plant extracts could be due to method of extraction, extraction solvent, nature and origin of the plants (Odhiambo et al. 2009; Javaid and Rehman, 2011; Mahlo et al., 2013). The effectiveness of plant extracts is also influenced by sensitivity of test pathogen strain and concentration of the extract (Bandor et al. 2013; Agbenin and Marley, 2012; Brussoti et al., 2013). Dabur et al. (2007) reported that water extracts were more effective than organic extracts while Bandor et al. (2013) reported that use of water in extraction increases the amount of impurities and this could impair the quality of extracts.

The observed antimicrobial effect of turmeric could be attributed to presence of volatile compounds such as flavonoids, alkaloids, saponins, tannins, terpenoids, polyphenolics and polyacetate derivatives (Mizubuti et al., 2007; Javaid and Rehman, 2011; Reddy et al., 2012). Different plant families have different bioactive compounds including curcuminoids and turmerones, (Damalas, 2011), $\alpha$ and $\beta$-phellandrene and limonene, piperitone and piperitonone which inhibit spore germination, alter hypha modifications and modify the structure of mycelia of fungal pathogens (Vidyasagar and Tabassum, 2013). The major active compounds are aromatic oils, turmerones and curcuminoids (Damalas, 2011; Wongkaew and Sinsiri, 2014). These compounds impair growth and development of pests through contact and interference with their physiological functions (Effiom et al., 2012; Sumitra et al., 2012). Nature and origin of the plants dictate the type and amount of bioactive compounds present (Nashwa and Abo-Elyousr, 2012). The physiology and growth rate of the test fungal pathogens also affect the activity of the extracts since some microorganisms are fast growers and others have sophisticated morphologies (Mizubuti et al., 2007). Different concentrations are needed for efficacy from different plant extracts and against different pathogens (Javaid and Rehman, 2011).

The results of this study showed that plants available in local environment is a potential source of active compounds that could be exploited for environmentally safe pest control products to be used in sustainable agricultural production. 
Table 1. Percentage inhibition of colony diameter of different tomato plant pathogens cultured on PDA amended with crude plant extracts at 8 days after incubation.

\begin{tabular}{lllll}
\hline Source of extracts & Pythium & Alternaria & Rhizoctonia & Fusarium \\
\hline Turmeric & $55.6 \mathrm{a}$ & $72.9 \mathrm{a}$ & $33.5 \mathrm{a}$ & $36.7 \mathrm{a}$ \\
Garlic & $20.5 \mathrm{de}$ & $43.5 \mathrm{~b}$ & $24.7 \mathrm{~b}$ & $8.7 \mathrm{~d}$ \\
Lemon & $49.3 \mathrm{a}$ & $35.0 \mathrm{c}$ & $14.4 \mathrm{c}$ & $4.9 \mathrm{f}$ \\
Pepper & $29.3 \mathrm{~cd}$ & $15.9 \mathrm{de}$ & $35.6 \mathrm{a}$ & $27.5 \mathrm{~b}$ \\
Ginger & $31.5 \mathrm{bc}$ & $37.9 \mathrm{bc}$ & $0.0 \mathrm{c}$ & $4.8 \mathrm{ef}$ \\
Rosemary & $44.7 \mathrm{ab}$ & $22.4 \mathrm{~d}$ & $0.0 \mathrm{c}$ & $4.7 \mathrm{f}$ \\
Neem & $14.0 \mathrm{e}$ & $8.0 \mathrm{f}$ & $0.0 \mathrm{c}$ & $7.0 \mathrm{de}$ \\
Aloe & $17.3 \mathrm{de}$ & $9.3 \mathrm{f}$ & $0.0 \mathrm{c}$ & $2.3 \mathrm{~g}$ \\
Mint & $20.9 \mathrm{de}$ & $9.8 \mathrm{ef}$ & $0.0 \mathrm{c}$ & $8.5 \mathrm{~d}$ \\
Marigold & $45.5 \mathrm{ab}$ & $11.6 \mathrm{ef}$ & $0.0 \mathrm{c}$ & $11.0 \mathrm{c}$ \\
\hline LSD $(\mathrm{p} \leq 0.05)$ & 11.6 & 6.8 & 5.5 & 2.1 \\
s.e & 4.03 & 2.34 & 1.91 & 1.15 \\
CV $(\%)$ & 26.7 & 19.3 & 38.9 & 13.8 \\
\hline
\end{tabular}

Means followed by the same letter(s) within each column do not differ significantly at P $\leq 0.05$. LSD - least significant difference, CV - coefficient of variation, s.e standard error (treatments had an equal number of replications).

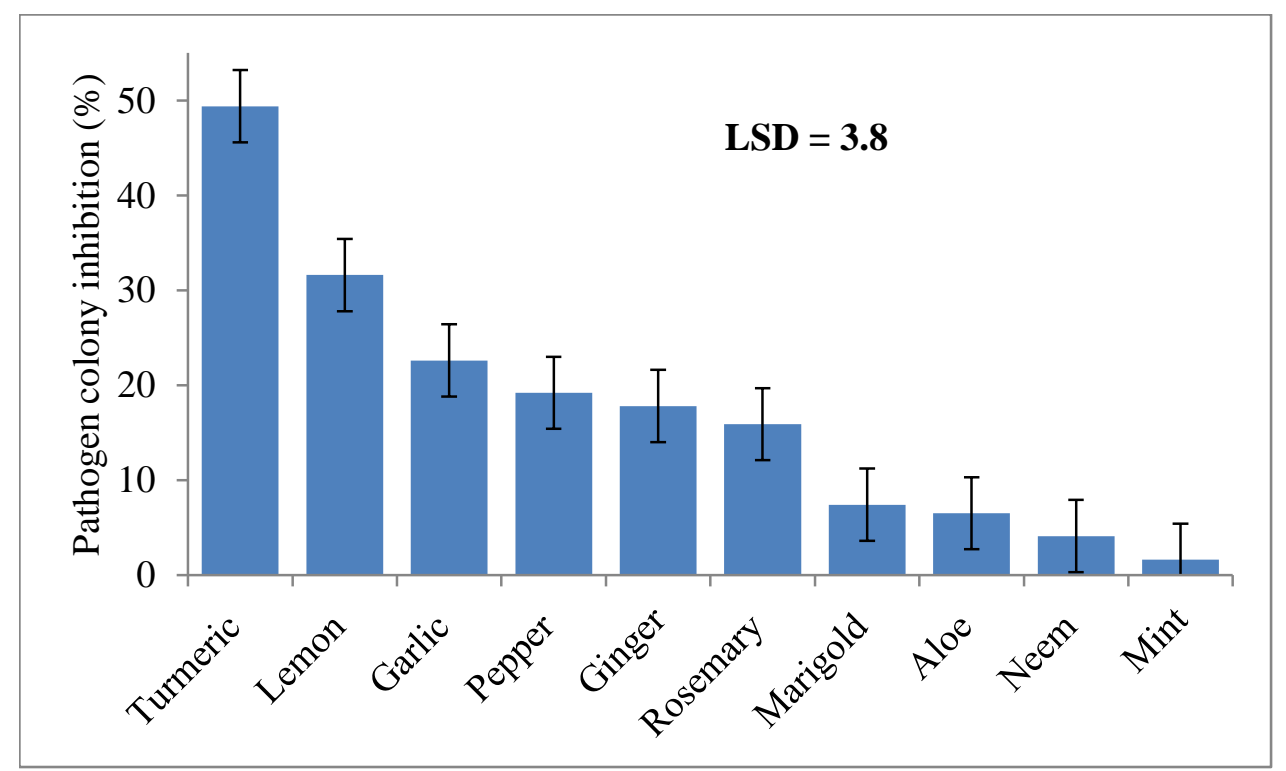

Fig 1. Percent reduction in colony diameters of fungal pathogens grown on agar media amended with extracts from different plants.

Table 2. Percentage inhibition of colony diameter of Alternaria solani cultured on PDA amended with crude plant extracts.

\begin{tabular}{lllll}
\hline Source of extracts & \multicolumn{4}{c}{ Days after incubation } \\
\cline { 2 - 5 } & 2 & 4 & 6 & 8 \\
\hline Turmeric & $100.0 \mathrm{a}$ & $80.4 \mathrm{a}$ & $78.6 \mathrm{a}$ & $73.6 \mathrm{a}$ \\
Garlic & $100.0 \mathrm{a}$ & $70.7 \mathrm{a}$ & $61.9 \mathrm{~b}$ & $45.0 \mathrm{~b}$ \\
Lemon & $75.8 \mathrm{~b}$ & $43.7 \mathrm{~b}$ & $37.5 \mathrm{~d}$ & $36.8 \mathrm{c}$ \\
Pepper & $59.0 \mathrm{~d}$ & $32.1 \mathrm{bc}$ & $26.8 \mathrm{e}$ & $18.2 \mathrm{e}$ \\
Ginger & $62.5 \mathrm{c}$ & $37.8 \mathrm{bc}$ & $49.4 \mathrm{c}$ & $39.6 \mathrm{c}$ \\
Rosemary & $53.7 \mathrm{e}$ & $32.1 \mathrm{bc}$ & $27.4 \mathrm{e}$ & $24.6 \mathrm{~d}$ \\
Neem & $36.4 \mathrm{~g}$ & $20.5 \mathrm{c}$ & $15.7 \mathrm{f}$ & $10.3 \mathrm{~g}$ \\
Aloe & $39.2 \mathrm{f}$ & $20.6 \mathrm{c}$ & $17.3 \mathrm{f}$ & $11.8 \mathrm{~g}$ \\
Mint & $57.0 \mathrm{~d}$ & $25.0 \mathrm{c}$ & $15.6 \mathrm{f}$ & $14.8 \mathrm{ef}$ \\
Marigold & $51.3 \mathrm{e}$ & $44.6 \mathrm{~b}$ & $18.6 \mathrm{f}$ & $14.1 \mathrm{f}$ \\
\hline LSD $(\mathrm{P} \leq 0.05)$ & 2.9 & 19.1 & 7.7 & 3.6 \\
S.e & 10.3 & 8.3 & 3.0 & 2.2 \\
C V $(\%)$ & 3.4 & 35.7 & 16.7 & 9.5 \\
\hline
\end{tabular}

Means followed by the same letter(s) within each column do not differ significantly at P $\leq 0.05$. LSD - least significant difference, CV - coefficient of variation, s.e standard error (treatments had an equal number of replications). 
Table 3. Percentage inhibition of colony diameter of Pythium ultimum cultured on PDA amended with crude plant extracts.

\begin{tabular}{lllll}
\hline Source of extracts & \multicolumn{4}{c}{ Days after incubation } \\
\cline { 2 - 5 } & 2 & 4 & 6 & 8 \\
\hline Turmeric & $71.9 \mathrm{a}$ & $70.5 \mathrm{a}$ & $69.2 \mathrm{a}$ & $67.4 \mathrm{a}$ \\
Garlic & $45.5 \mathrm{e}$ & $18.6 \mathrm{f}$ & $24.7 \mathrm{c}$ & $28.7 \mathrm{c}$ \\
Lemon & $66.7 \mathrm{~b}$ & $45.3 \mathrm{~b}$ & $36.5 \mathrm{~b}$ & $33.0 \mathrm{~b}$ \\
Pepper & $12.5 \mathrm{~h}$ & $2.5 \mathrm{i}$ & $1.6 \mathrm{~g}$ & $5.9 \mathrm{~g}$ \\
Ginger & $59.7 \mathrm{c}$ & $23.9 \mathrm{e}$ & $25.6 \mathrm{c}$ & $27.6 \mathrm{c}$ \\
Rosemary & $49.2 \mathrm{~d}$ & $31.9 \mathrm{c}$ & $35.8 \mathrm{~b}$ & $37.4 \mathrm{c}$ \\
Neem & $12.5 \mathrm{~h}$ & $4.5 \mathrm{~h}$ & $3.1 \mathrm{f}$ & $8.5 \mathrm{f}$ \\
Aloe & $31.2 \mathrm{f}$ & $12.2 \mathrm{~g}$ & $9.2 \mathrm{e}$ & $5.9 \mathrm{f}$ \\
Mint & $17.7 \mathrm{~g}$ & $2.3 \mathrm{i}$ & $17.5 \mathrm{~d}$ & $11.4 \mathrm{e}$ \\
Marigold & $46.6 \mathrm{e}$ & $27.2 \mathrm{~d}$ & $24.4 \mathrm{c}$ & $23.0 \mathrm{~d}$ \\
\hline LSD P $\leq 0.05)$ & 2.6 & 1.7 & 1.7 & 2.5 \\
s.e & 6.94 & 4.34 & 5.65 & 3.33 \\
C V $(\%)$ & 4.8 & 5.4 & 5.3 & 8 \\
\hline
\end{tabular}

Means followed by the same letter(s) within each column do not differ significantly at P $\leq 0.05$. LSD - least significant difference, CV - coefficient of variation, s.e standard error (treatments had an equal number of replications).

Table 4. Percentage inhibition of colony diameter of Fusarium oxysporum f.sp. lycopersici cultured on PDA amended with crude plant extracts.

\begin{tabular}{lllll}
\hline \multirow{2}{*}{ Source of extracts } & \multicolumn{4}{c}{ Days after incubation } \\
\cline { 2 - 5 } & 2 & 4 & 6 & 8 \\
\hline Turmeric & $48.5 \mathrm{a}$ & $46.7 \mathrm{a}$ & $48.6 \mathrm{a}$ & $39.1 \mathrm{a}$ \\
Garlic & $36.8 \mathrm{~b}$ & $16.7 \mathrm{c}$ & $9.0 \mathrm{e}$ & $6.6 \mathrm{~d}$ \\
Lemon & $32.4 \mathrm{~b}$ & $39.2 \mathrm{~b}$ & $40.3 \mathrm{~b}$ & $31.5 \mathrm{~b}$ \\
Pepper & $17.8 \mathrm{c}$ & $12.5 \mathrm{~d}$ & $2.7 \mathrm{dg}$ & $3.1 \mathrm{def}$ \\
Ginger & $30.9 \mathrm{~b}$ & $3.3 \mathrm{fg}$ & $5.6 \mathrm{fg}$ & $5.4 \mathrm{def}$ \\
Rosemary & $14.7 \mathrm{~d}$ & $8.3 \mathrm{e}$ & $3.1 \mathrm{fg}$ & $3.3 \mathrm{def}$ \\
Neem & $8.7 \mathrm{e}$ & $10.8 \mathrm{e}$ & $2.8 \mathrm{fg}$ & $2.7 \mathrm{ef}$ \\
Aloe & $5.8 \mathrm{f}$ & $14.6 \mathrm{~cd}$ & $6.3 \mathrm{ef}$ & $4.9 \mathrm{def}$ \\
Mint & $5.7 \mathrm{f}$ & $4.2 \mathrm{fg}$ & $16.0 \mathrm{~d}$ & $19.9 \mathrm{c}$ \\
Marigold & $5.7 \mathrm{f}$ & $12.4 \mathrm{~d}$ & $28.9 \mathrm{c}$ & $23.2 \mathrm{c}$ \\
\hline LSD P $\leq 0.05)$ & 6 & 3.7 & 4.6 & 3.3 \\
s.e & 2.93 & 1.55 & 2.238 & 1.834 \\
C V $(\%)$ & 22.2 & 16.5 & 21.3 & 18.1 \\
\hline
\end{tabular}

Means followed by the same letter(s) within each column do not differ significantly at P $\leq 0.05$. LSD - least significant difference, CV - coefficient of variation, s.e standard error (treatments had an equal number of replications).

Table 5. Percentage inhibition of colony diameter of Rhizoctonia solani cultured on PDA amended with crude plant extracts.

\begin{tabular}{lllll}
\hline Source of extracts & \multicolumn{4}{c}{ Days after incubation } \\
\cline { 2 - 5 } & 2 & 4 & 6 & 8 \\
\hline Turmeric & $82.3 \mathrm{a}$ & $62.7 \mathrm{a}$ & $43.8 \mathrm{a}$ & $36.0 \mathrm{a}$ \\
Garlic & $72.3 \mathrm{~b}$ & $55.6 \mathrm{~b}$ & $37.1 \mathrm{~b}$ & $24.7 \mathrm{~b}$ \\
Lemon & $56.4 \mathrm{c}$ & $45.9 \mathrm{c}$ & $32.1 \mathrm{c}$ & $20.0 \mathrm{c}$ \\
Pepper & $57.3 \mathrm{c}$ & $55.9 \mathrm{~b}$ & $45.6 \mathrm{a}$ & $35.6 \mathrm{a}$ \\
Ginger & $35.9 \mathrm{e}$ & $18.6 \mathrm{e}$ & $5.3 \mathrm{e}$ & $0.0 \mathrm{~d}$ \\
Rosemary & $43.0 \mathrm{~d}$ & $47.4 \mathrm{c}$ & $14.1 \mathrm{~d}$ & $0.0 \mathrm{~d}$ \\
Neem & $42.7 \mathrm{~d}$ & $22.1 \mathrm{e}$ & $13.5 \mathrm{~d}$ & $0.0 \mathrm{~d}$ \\
Aloe & $55.9 \mathrm{c}$ & $28.5 \mathrm{~d}$ & $13.5 \mathrm{~d}$ & $0.0 \mathrm{~d}$ \\
Mint & $10.9 \mathrm{f}$ & $0.0 \mathrm{f}$ & $0.0 \mathrm{f}$ & $0.0 \mathrm{~d}$ \\
Marigold & $9.8 \mathrm{f}$ & $0.0 \mathrm{f}$ & $0.0 \mathrm{f}$ & $0.0 \mathrm{~d}$ \\
\hline LSD P $\leq 0.05)$ & 4.1 & 4.2 & 4.1 & 2.1 \\
s.e & 7.53 & 5.73 & 6.72 & 7.64 \\
C V $(\%)$ & 6.8 & 9.6 & 15.2 & 13.5 \\
\hline
\end{tabular}

Means followed by the same letter(s) within each column do not differ significantly at P $\leq 0.05$. LSD - least significant difference, CV - coefficient of variation, s.e standard error (treatments had an equal number of replications).

Botanical pesticides such as pyrethroids, neem and essential oils of higher plants have been shown to be as effective as the synthetic chemicals in reducing pest damage and have been commercialized. Botanical pesticides are relatively safe, have no effect on non-target organisms, are often effective in small quantities, decompose quickly and therefore have less residual effects and, therefore, acceptable to consumers (Gupta and Dikshit, 2010; Gurjar et al., 2012; Thoeming and Poehling, 2006). However, biopesticides have low storage stability, are susceptible to environmental conditions and 
some vary in their efficacy (Gašić and Tanović, 2013). In spite of this, the demand for pesticide residue free agricultural produce would warrant increased adoption of natural-based pesticides.

\section{Materials and methods}

\section{Plant materials}

Source of antimicrobial extracts included leaves, roots, flowers, fruits, rhizomes and cloves of mature plants collected from the field or purchased from a local market in Nairobi. The plants included turmeric (Curcuma longa) rhizomes, garlic (Allium sativum) cloves, ginger (Zingiber officinale) rhizomes, rosemary (Rosmarinus officinalis) leaves, pepper (Capsicum frutescens) fruits, lemon (Citrus limon) fruits, mint (Mentha piperita) leaves, neem (Azadirachta indica) leaves, aloe (Aloe vera) leaves and Mexican marigold (Tagetes minuta) flowers. The selection of the plants was based on the antimicrobial history from published reports by different researchers (Goufo et al., 2010; Al-Samarrai et al., 2012).

\section{Extraction of antifungal products from plants}

Crude extracts from plant samples were extracted using the modified method described by Al-Samarrai et al. (2012). The plant samples were washed under running tap water and rinsed in distilled water. The plant materials were finely blended in sterile distilled water and $100 \mathrm{~g}$ of the ground material was extracted with $500 \mathrm{ml}$ of $95 \%$ ethanol on a mechanical shaker for 30 minutes. Plant residues were removed by passing the mixture through two layers of cheese cloth followed by filtration through Whatman No. 2 filter paper. The alcohol in the filtrate was evaporated under vacuum in a rotary evaporator at $60^{\circ} \mathrm{C}$ and $10 \mathrm{ml}$ of the concentrated extract was stored in a refrigerator at $4^{0} \mathrm{C}$.

\section{Isolation of pathogens and antimicrobial activity assays}

Fungal pathogens tested were Alternaria solani, Pythium ultimum, Rhizoctonia solani and Fusarium oxysporum f. sp. lycopersici. Pathogens were isolated from diseased tomato plants, washed under running tap water, cut into $3 \mathrm{~mm}$ pieces, sterilized in 2-3\% sodium hypochlorite and rinsed in three changes of sterile distilled water. The sterilized plant tissues were blot dried and plated on Potato Dextrose Agar (PDA) amended with streptomycin antibiotic to suppress growth of bacteria and incubated at room temperature $\left(25-28^{\circ} \mathrm{C}\right)$. The isolated fungi were purified by sub-culturing on fresh PDA medium. The extracts were tested for antifungal activity by poisoned food technique as described by Al-Samarrai et al. (2012). Plant extracts were incorporated into molten PDA media cooled to $45^{\circ} \mathrm{C}$ at a ratio of $1 \mathrm{ml}$ extract to $50 \mathrm{ml}$ media $(\mathrm{v} / \mathrm{v})$. The molten media containing the extract was dispensed into Petri dishes and allowed to set. Agar discs $(5 \mathrm{~mm})$ were cut from 14-day old fungal pathogen cultures and plated on the PDA containing the plant extracts. Control plates contained PDA medium without extracts. The cultures were incubated at room temperature for up to 14 days. Diameter of the pathogen colonies was measured at the second, fourth, sixth and eighth day after plating and the antifungal activity of each extract was determined by calculating the reduction in the fungal colony radial growth using the following formula:

\author{
$\%$ inhibition \\ (Colony diameter without extract - Colony diamter with extract) \\ Colony diameter without extract \\ * 100 \\ Data analysis
}

The experiments were laid out in randomized complete block design with the extracts as the treatments and replicated four times. The experiment was repeated twice. Data collected was subjected to analysis of variance using Genstat ${ }^{\circledR} 15^{\text {th }}$ Edition software and the means separated using Fischer's Protected LSD at 5\% probability level (Steel and Torrie, 1990).

\section{Conclusion}

The study shows that locally available plants have antifungal properties which if tapped using appropriate procedures and concentrations, could be formulated and availed to farmers as pesticides. The inhibition levels reported show that they have potential to manage plant pathogens and hence could replace pesticides upon formulation. Comprehensive explorations need to be done into the local environments for more plants with antimicrobial properties. Their bioactive compounds should also be identified and formulated into pesticides which are safe for use compared to the synthetic pesticides.

\section{Acknowledgement}

This project was funded by Regional Universities Forum for Capacity Building in Agriculture (RUFORUM) Grant under the Competitive Grants System, Project No.RU/2014/GRG-096

\section{References}

Agbenin ON and Marley PS (2006) In vitro assay of some plant extracts against Fusarium oxysporumfsp. lycopersici causal agent of tomato wilt. J Plant Prot Res. 46(3): 215220.

Aktar MW, Sengupta D, Chowdhury A (2009) Impact of pesticide use in Indian agriculture - their benefits and hazards. Interdiscip Toxicol. 2(1):1-12.

Al-Samarrai G, Singh H and Syarhabil M (2012) Evaluating eco-friendly botanicals (natural plant extracts) as alternatives to synthetic fungicides. Ann Agric Environ Med. 9: 673-676.

Bandor H, Hijazi A, Rammal H, Hachem A, Saad Z and Badran B (2013) Techniques for the extraction of bioactive compounds from labaneseUrticadiotica. Am J Phytomedicine Clinical Therapeutics. 1(6): 507-513.

Bhattacharjee R and Dey U (2014) An overview of fungal and bacterial biopesticides to control plant pathogens and diseases. Afr J Microbiol Res. 8(7): 1749-1769.

Birech R, Bernhard F, Joseph M (2006) Towards reducing synthetic pesticides imports in favour of locally available botanicals in Kenya. Paper presented at a conference on international agricultural research for development, Bonn, Germany, $11^{\text {th }}$ To $13^{\text {th }}$ October 2006.

Brusotti G, Cesain I, Dentamaro A, caccialanza G and Massolin G (2013) Isolation and characterization of bioactive compounds from plant resources: the role of analysis in the ethnopharmacological approach. J Pharm Biomed Anal. 87: 218-228.

Business Daily (2014a) Chemical ban hits vegetable exports to the EU market. 19 ${ }^{\text {th }}$ March 2014. 
Business Daily (2014b) EU agency to probe horticultural sector on safety concerns. $19^{\text {th }}$ March 2014.

Business Daily (2014c) EU shuns Kenya fresh produce on safety concerns. $19^{\text {th }}$ March 2014.

Business Daily (2016) Fresh exports gets boost as KEPHIS to monitor EU sales. $29^{\text {th }}$ May 2016.

Cawoy H, Bettiol W, Fickers P and Ongena M (2011) Bacillus-Based Biological Control of Plant Diseases. Pesticides in the Modern World - Pesticides Use and Management. Ed. Margarita Stoytcheva. In Tech ISBN 978-953-307-459-7: 273-302

Charlie N (2014) New biopesticides controls tomato blight and mildews, National gardening association. www.garden.org/article/articles.php?.q=show=3077. Accessed 25/01/2015

Chethana BS, Ganeshan G, Rao AS and Bellishree K (2012) In-vitro evaluation of plant extracts, bioagents and fungicides against Alternaria porri (Ellis) Cif., causing purple blotch diseases of onions. Pest Manag Hort Ecosyst. 18(2): 194-198.

Dabur R, Gupta A, Mandal TK, Singh DD, Bajpai V, Guvar AM and Lavekar GS (2007) Antimicrobial activity of some Indian medicinal plants. Afr J Tradit Complement Altern Med. 4(3): 313-318.

Damalas AD (2011) Potential uses of turmeric (Curcuma longa) products as alternative means of pest management in crop production. Plant Omics. 4(3): 136-141.

Effiom OE, Avoaja DA, Ohaeri CC (2012) Mosquito repellent activity of phytochemical extracts from peels of citrus fruit species. Global J Sci Front Res. 12(1): 4-8.

Engindeniz S, Ozturk GC (2013) An economic comparison of pesticide application for processing and table tomatoes, a case study for Turkey. J Plant Prot Res. 53(3): 230-237.

European Commission (2012) Amending Annex I to Regulation (EC) No 669/2009 implementing Regulation (EC) No 882/2004 of the European Parliament and of the Council as regards the increased level of official controls on imports of certain feed and food of non-animal origin. Official Journal of the European Union. L. 350/44. 20/12/2012.

Gašić S, Tanović B (2013) Biopesticide formulations, possibility of application and future trends. Pestic Phytomed. (Belgrade), 28(2): 97-102.

Ghorbani R, Wilcockson S, Leifert C (2005) Alternative treatments for late blight control in organic potato: antagonistic micro-organisms and compost extracts for activity against Phytophthora infestans. Potato Res. 48: 181-189.

Goufo P, Fontem A, Ngnokam D (2010) Evaluation of plant extracts for tomato late blight in Cameroon. NZ J Crop Hortic Sci. 38(3): 171-176.

Gupta S, Dikshit AK (2010) Biopesticides: an ecofriendly approach for pest control. J Biopest. 3(1):186 - 188.

Gurjar MS, Ali S, Masood Akhtar M, Singh KS (2012) Efficacy of plant extracts in plant disease management. Agric Sci. 3: 425-433.

Javaid A and Rehman A H (2011) Antifungal activity of leaf extracts of some medicinal trees against Macrophomina phaseolina. J Med Plants Res. 5(13): 2858-2872.

Kenya Plant Health Inspectorate Services (KEPHIS) (2012) The introduction of increased checks on Kenyan exported beans and peas in pods by the European Union. http://www.kephis.org/99-regulation669amended.html.

Mahajan S, Gupta A and Sharma R (2015) Evaluation of antimicrobial activity of Curcuma longa rhizome extract against Staphylococcus aureus. Biotechnol Rep. 6: 51-55.
Mahlo S M, Chauk H R, McGaw L J and Eloff J N (2013) Antioxidant and antifungal activity of selected plant species used in traditional medicine. J Med Plants Res. 7(33): 2444-2450.

Mizubuti G S E and, Junior V L and Forbes G A (2007) Management of late blight with alternative products. Pest Technol. 1(2):106-116.

Mohammed EEM (2014) Natural enemies of the tomato leaf miner (Tuta absoluta) in Kassala State, Sudan. Paper presented at the third conference on pest management, Medani, Sudan, $3^{\text {rd }}-4^{\text {th }}$ February 2014.

Nashwa MAS (2011) Control of tomato early blight disease by certain aqueous plant extracts. Plant Pathol J. 10(4): 187-191.

Nashwa SMA and Abo-Elyousr AMK (2012) Evaluation of various plants extracts against the early blight disease of tomato plants under green house and field conditions. Plant Prot Sci. 48(2): 74-79.

Nderitu J H, Mwangi F, Nyamasyo G, and Kasina M (2010) Utilization of synthetic and botanical insecticides to manage thrips (thysan.: thrip.) on snap beans (fabaceae) in Kenya. Int J Sustain Crop Prod. 5(1):1-4.

Nwachukwu ID and Asawalam EF (2014) Evaluation of freshly prepared juice from garlic (Allium sativum L)as a biopesticide against the maize weevil, Sitophillus zeamais (Motcsh.) (Coloptera: Curculionidae). J Plant Prot Res. 54: 132-138.

Odhiambo AJ, Siboe GM, Lukhoba CW, Dossaji FS (2009) Antifungal activity of crude extracts of selected medicinal plants used in combination in Lake Victoria basin, Kenya. Plant Product Res J. 13:35-43.

Prasad A and Syed N (2010) Evaluating prospects of fungal biopesticide Beauveria bassiana (Balsamo) against Helicoverpa armigera (Hubner): an ecosafe strategy for pesticidal pollution. Asian J Exp Biol Sci. 1 (3):596-601.

Reddy MN, Mishra JG, Lathiya DG (2012) In vitro antifungal activity of aqueous extracts of some medicinal plants against Aspergillus niger. Int J of Biomed Res. 3(1): 5-8.

Rodino S, Butu M, Petrache P, Butu A, Cornea PC (2014) Antifungal activity of four plant extracts against Alternaria alternata, Scientific Bulletin Series F, Biotechnologies 6065.

Shiberu T and Getu E (2016) Assessment of selected botanical extracts against Liriomyza species (Diptera: Agromyzidae) on tomato under glasshouse condition. Int $\mathbf{J}$ Fauna Biol Stud. 3(1): 87-90.

Siginon Group (2015) "Perishable cargo remains Kenya's competitive advantage, http://siginon.com/blog/?p=8 accessed May 2016

Song CH, Islam R Md., Jeong YT and Lee YS (2012) Isolation and identification of antifungal compounds from Bacillus subtilis c9 inhibiting the growth of plant pathogenic fungi. Mycobiology. 40(1): 59-66.

Srijita D (2015) Biopesticides: an eco-friendly approach for pest control. World J Pharmacy and Pharmaceutical Sci. 4 (6): 250-265.

Stangarlin JR, Kuhn OJ, Assi L and Schwan-Estrada KRF (2011) Control of plant diseases using extracts from medicinal plants and fungi. Formatex. 1033-1042.

Steel RGD and Torrie JH (1981) Principles and procedures of statistics: A biometrical approach, $2^{\text {nd }}$ edition. McGrawHill Book Company, Singapore, 633p.

Sumitra A, Kanojia AK, Kumar A, Mogha N and Sahu V (2012) Biopesticide formulation to control tomato lepidopteran pest menace. Curr Sci. 102 (7): 1051-1057. 
The East African (2015) Kenya at risk of losing EU markets for peas, beans due to falling standard. $25^{\text {th }}$ April 2015

Thoeming G and Poehling HM (2006) Integrating soilapplied Azadirachtin with Amblyseius cucumeris (Acari: Phytoseiidae) and Hypoaspis aculeifer (Acari: Laelapidae) for the management of Frankliniella occidentalis (Thysanoptera: Thripidae). Environ Entomol. 35: 746-756.

Vidyasagar GM and Tabassum N (2013). Antifungal investigations on plant essential oils; a review. Int J Pharm Pharm Sci. 5 (2): 19-28.
Wagnitz JJ (2014) Biopesticides use in IPM for low desert vegetable and fruit production, Paper AA13618603, Degree of Doctor of Philosophy in Plant Health, College of Agricultural Sciences and Natural Resources, ETD Collection for University Of Nebraska, Lincoln.

Wongkaew P and Sinsiri W (2014) Effectiveness of ringworm cassia and turmeric plant extracts on growth inhibition against some important plant pathogenic fungi. Am J Plant Sci. 5:616-626. 